\title{
Seizures in patients with respiratory disease - a retrospective single center study
} Convulsões em pacientes com doença respiratória - estudo retrospectivo de centro único Senay AYDIN¹, Cengiz ÖZDEMIR², Ayșegül GÜNDÜZZ3, Meral E. KIZILTAN

\begin{abstract}
Objective: Seizures are a neurological condition commonly experienced during the follow-up period after systemic or metabolic disorders. The aim of the present study was to determine the etiological factors of seizures in patients at a tertiary care chest clinic. Methods: We reviewed all neurology consultations that were requested due to seizures in inpatient clinics in a tertiary care hospital specializing in respiratory disorders between January 2011 and January 2018 were retrospectively reviewed. Results: The present study included 705 of 2793 (25.2\%) patients who requested consultations for seizures during the study period. The mean age of the sample was $64.05 \pm 17.19$ years. Of the 705 patients, 307 ( $43.5 \%$ ) had a previous history of epilepsy (Group I) and 398 (56.5\%) had a first-time seizure and were considered to have symptomatic seizures (Group II). Multiple factors played roles in the development of seizures in $54.8 \%$ of the patients. In most patients, metabolic causes, systemic infections, and drug use were identified and an intracranial metastatic mass lesion was the major cause in patients with lung cancer. Rates of hypoxemia and respiratory acidosis were significantly higher in patients with symptomatic seizures (Group II) than in patients with primary epilepsy (Group I). Conclusions: Blood gas changes such as hypoxemia and respiratory acidosis were among the factors statistically associated with the development of symptomatic seizures in patients with respiratory diseases. Additionally, hypoxemia, hypercapnia, and respiratory acidosis were correlated with mortality in patients hospitalized for respiratory system diseases who requested consultations for seizures.
\end{abstract}

Keywords: seizures; respiratory diseases; hypoxemia; hypercapnia; respiratory acidosis.

\section{RESUMO}

Objetivo: Convulsões são uma condição neurológica comumente vivenciada durante o período de acompanhamento após distúrbios sistêmicos ou metabólicos. 0 objetivo do presente estudo foi determinar os fatores etiológicos das convulsões em pacientes de uma clínica torácica de atendimento terciário. Métodos: Foram revisadas retrospectivamente todas as consultas neurológicas solicitadas devido a convulsões em clínicas de internação em um hospital terciário especializado em distúrbios respiratórios entre janeiro de 2011 e janeiro de 2018. Resultados: O presente estudo incluiu 705 dos 2.793 (25,2\%) pacientes que solicitaram consultas para convulsões durante o período

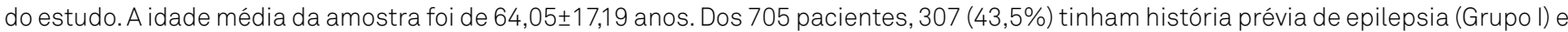
398 (56,5\%) tiveram uma convulsão inicial e foram considerados como tendo crises sintomáticas (Grupo II). Vários fatores desempenharam papel no desenvolvimento de convulsões em $54,8 \%$ dos pacientes. Na maioria dos pacientes, causas metabólicas, infecções sistêmicas e uso de drogas foram identificadas e uma lesão em massa metastática intracraniana foi a principal causa em pacientes com câncer de pulmão. As taxas de hipoxemia e acidose respiratória foram significativamente maiores em pacientes com crises sintomáticas (Grupo II) do que em pacientes com epilepsia primária (Grupo I). Conclusões: Alterações dos gases sanguíneos, como hipoxemia e acidose respiratória, foram alguns dos fatores estatisticamente associados ao desenvolvimento de convulsões sintomáticas em pacientes com doenças respiratórias. Além disso, hipoxemia, hipercapnia e acidose respiratória foram correlacionadas com a mortalidade em pacientes hospitalizados por doenças do sistema respiratório que solicitaram consultas para convulsões.

Palavras-chave: convulsões; doenças respiratórias; hipóxia; hipercapnia; acidose respiratória.

Seizures are a common neurological condition and can occur during the follow-up period after chronic disorders. All metabolic alterations that may develop during chronic diseases, as well as the medications used to treat these diseases (e.g., antibiotics, antivirals, antidepressants, and antipsychotics), can cause symptomatic seizures without causing

${ }^{1}$ Department of Neurology, Yedikule Chest Diseases and Chest Surgery Training and Research Hospital, Istanbul, Turkey. ${ }^{2}$ Department of Pulmonology, Yedikule Chest Diseases and Chest Surgery Training and Research Hospital, Istanbul, Turkey. ${ }^{3}$ Department of Neurology, Istanbul University - Cerrahpasa, Cerrahpasa Medical Faculty, Istanbul, Turkey. Senay AYDIN ID https://orcid.org/0000-0003-4460-9056; Cengiz ÖZDEMIR iD https://orcid.org/0000-0002-9816-8885; Ayșegül GÜNDÜZ ID https://orcid.org/0000-0003-2365-0850; Meral E. KIZILTAN iD https://orcid.org/0000-0003-0538-3736

Correspondence: Șenay Aydın; Yedikule Chest Diseases and Chest Surgery Training and Research Hospital, Department of Neurology, 34020 , ZeytinburnuIstanbul-Turkey; E-mail: aydin.senay@hotmail.com

Conflict of interest: There is no conflict of interest to declare.

Received on March 28, 2019; Received in its final form on October 03, 2019; Accepted on November 22, 2019. 
direct structural damage to the brain. However, seizures can also occur secondarily to structural damage to the central nervous system (CNS) due to systemic disease ${ }^{1,2}$. For example, symptomatic seizures can manifest due to the effects of various acute medical or toxic conditions in the CNS, and the resulting organic brain damage and neurological dysfunction can cause recurrent seizures ${ }^{3,4}$. The most common systemic diseases involved in the etiology of seizures include a wide range of cardiopulmonary diseases, such as long QT syndrome, bradycardia, rhythm disturbances (e.g., asystole), systemic hypertension (HT), pulmonary embolism, and pulmonary hypertension, and disturbances in cerebral perfusion have also been implicated in the pathophysiology of seizures $^{5-8}$. Similar to the presence of systemic comorbidities, the presence of seizures may considerably affect the course of a respiratory disease, treatment for this disease, and length of hospital stay. Thus, the aim of the present study was to determine the etiological factors and correlate them with specific outcomes in patients hospitalized in chest clinics who had seizures during hospitalization.

\section{METHODS}

All neurology consultations requested for patients with seizures who were being treated at an inpatient tertiary Chest Diseases and Thoracic Surgery Training and Research Hospital between January 2011 and January 2018 were retrospectively reviewed. The study protocol was approved by local clinical trials ethics committee (Approval number: 2018/1496). Patients diagnosed with seizures according to the International League Against Epilepsy (ILAE) guidelines were included in this study and categorized into two groups: patients with a previous diagnosis of primary epilepsy who received antiepileptic medications were included in Group I, and patients without a previous history of seizures who had an epileptic seizure for the first time during their hospital stay were considered to have symptomatic seizures and were included in Group II.

Age, gender, the presence of primary epilepsy, comorbidities, primary diagnosis on admission, consultation requests, the last neurological condition on discharge, and all laboratory tests performed during the hospitalization period were retrieved and evaluated. The presence of comorbidities accompanying primary lung disease requiring hospitalization such as diabetes mellitus, hypothyroidism, hypercholesterolemia, HT, cerebrovascular disease, chronic renal failure, extra-thoracic malignancy, and any other systemic chronic diseases was recorded. Only patients with complete consultation notes and laboratory data were included in the study. Additionally, the electroencephalographic (EEG) data of all patients obtained during their hospitalization were assessed. Discharges of patients were classified as cured or exitus.
The following laboratory data from the pre-ictal period of each patient were analyzed: levels of blood glucose (BG; 70-100 mg/dL), blood urea (15-45 mg/dL), creatinine (male: 0.8-1.2 mg/dL and female: 0.7-1.3), uric acid (3.5-7.2 mg/dL), sodium ( $\mathrm{Na}^{+} ; 135-148 \mathrm{mEq} / \mathrm{L}$ ), white blood cells (WBC; 6-10 $\left.\mathrm{mm}^{3}\right)$, red blood cells (RBC; $\left.10^{6} / \mathrm{uL}\right)$, erythrocyte sedimentation rate (ESR; <30 mm/hour), C-reactive protein (CRP; <3 $\mathrm{mg} / \mathrm{L}$ ), $\mathrm{pCO}_{2}$ (35-45 mmHg) $\mathrm{pO}_{2}$ (80-100 mmHg), $\mathrm{HCO}_{3}$ (22$26 \mathrm{mEg} / \mathrm{lt})$, and $\mathrm{pH}$ (7.35-7.45). A BG value $>140 \mathrm{mg} / \mathrm{dL}$ was defined as hyperglycemia and a BG value $<70 \mathrm{mg} / \mathrm{dL}$ was defined as hypoglycemia ${ }^{9,10}$. Blood urea (10-50 mg/dL), uric acid (2.5-7.2 mg/dL), and creatinine (0.30-1.2 mg/dL) levels were evaluated in conjunction with clinical data to diagnose uremia. $\mathrm{A} \mathrm{PaCO}_{2}$ level $>45 \mathrm{mmHg}$ was defined as hypercapnia, a $\mathrm{PaO}_{2}$ level $<70 \mathrm{mmHg}$ was defined as hypoxemia, and an arterial $\mathrm{pH}<7.35$ was defined as acidosis. Additionally, factors associated with seizures, including systemic infection, metabolic variables, and the presence of drug use, were determined in all patients. Metabolic variables were defined as being accompanied by any pathological conditions in terms of BG, electrolytes, urea, creatinine, uric acid, and blood gas based on laboratory data findings.

\section{Statistical analysis}

SPSS version 22.0 (released in 2013, SPSS Statistics for Windows, IBM Corp.; Armonk, NY) was used for all statistical analyses. The minimum, maximum, median, standard deviation, frequency, and percentage values of all data were calculated. Chi-square tests were used to analyze categorical variables, t-tests were used to compare mean values of parametric variables, and a point-biserial correlation analysis was performed to assess the correlation between mortality and changes in all laboratory data. P-values $<0.05$ were considered to indicate statistical significance.

\section{RESULTS}

The present study initially assessed the data of 2793 inpatients for whom neurology consultations were requested between January 2011 and January 2018. Of these patients, the specific reason for a neurology consultation in 807 patients was a preliminary diagnosis of seizures. Of these patients, 102 were diagnosed as not having epileptic seizures. Thus, the clinical findings of 705 patients who were definitively diagnosed with seizures were further analyzed for the present study.

The 705 patients had a mean age of $64.05 \pm 17.19$ years (range: 20-97 years) and included 522 males (74.0\%) (Table 1). The consultations were requested by eight different units including the chest clinic $(n=393 ; 55.7 \%)$, thoracic surgery ward $(n=55 ; 7.8 \%)$, respiratory intensive care unit $(n=94$; $13.3 \%)$, thoracic surgery intensive care unit $(n=47 ; 6.7 \%)$, emergency department $(n=34 ; 4.8 \%)$, tuberculosis unit $(n=38$; 
$5.4 \%)$, transplantation unit $(\mathrm{n}=30 ; 4.3 \%)$, and palliative care unit $(n=14 ; 2.0 \%)$. The primary respiratory disease diagnoses of the patients included chronic obstructive pulmonary disease (COPD), lung cancer, pneumonia, and tuberculosis, and less commonly, hemoptysis, pleural effusion, asthma, pulmonary embolism, post-intubation tracheal stenosis, and pneumothorax. COPD and pneumonia were more common in Group 1, and lung cancer and hemoptysis were more common in Group 2 (Table 2).

For all patients, the most common factors that precipitated seizures were metabolic causes $(n=491,69.6 \%)$. Medications used for the treatment of primary respiratory disease were the etiological cause of seizures in 51 patients $(7.2 \%)$ and included anti-tuberculosis drugs such as isoniazid and rifampicin $(n=15)$, moxifloxacin $(n=10)$, macrolides $(n=7)$, meropenem $(n=7)$, ciprofloxacin $(n=3)$, ampicillin $(n=3)$, and mycophenolate mofetil $(n=2)$. In this group of patients in which medications were responsible for the seizures, the presence of more than one factor was associated with the seizures, including infections in 43 patients and metabolic causes in six patients. Only two patients who were followed-up after a lung transplantation developed posterior reversible encephalopathy syndrome (PRES) secondary to immunosuppressive therapy; no structural changes were observed on the control cranial imaging of these patients. Multiple factors were found to be involved in the etiology of seizures in $54.8 \%$ of patients.

Of the total patient group, 307 (43.5\%) had a previous history of epilepsy (Group I) and 398 (56.5\%) had symptomatic seizures (Group II). No differences were observed between these two groups in terms of age, gender, or the presence of comorbidities. However, metabolic causes, respiratory acidosis, and hypoxemia were significantly more common in Group II (Table 1); accordingly, the mean arterial $\mathrm{pO}_{2}$ and $\mathrm{pH}$ values were significantly lower in Group II than Group I (Table 3). Infection was the second most common cause of seizures, but this variable did not differ significantly between the groups ( $n=346 ; 49.1 \%$; $p=0.085)$. The presence of an intracranial mass was the most common cause of seizures in patients with lung cancer $(n=160 ; 46.2 \%)$, but the groups did

Table 1. General characteristics and seizures etiology.

\begin{tabular}{|c|c|c|c|c|c|}
\hline & & Total & Group I & Group II & $p$-value* \\
\hline Total, n (\%) & & 705 & 307 (43.5) & $398(56.5)$ & \\
\hline Age & & $64.05 \pm 17.19(20-97)$ & $64.04 \pm 17.43$ & $64.07 \pm 17.02$ & 0.985 \\
\hline \multirow{2}{*}{ Gender, n (\%) } & Male & $522(74.0)$ & $223(72.6)$ & $299(75.1)$ & \multirow{2}{*}{0.455} \\
\hline & Female & $183(26.0)$ & $84(27.4)$ & $99(24.9)$ & \\
\hline Comorbidity ${ }^{\dagger}, \mathrm{n}(\%)$ & & $380(53.9)$ & $157(51.1)$ & $223(56.0)$ & 0.197 \\
\hline \multicolumn{6}{|l|}{ Etiology, n (\%) } \\
\hline Metabolic change & & $491(69.6)$ & $201(65.5)$ & $290(72.9)$ & 0.034 \\
\hline Hypercapnia & & $323(45.8)$ & $148(48.2)$ & $175(44.0)$ & 0.263 \\
\hline Hypoxemia & & $269(38.2)$ & $104(33.9)$ & $165(41.5)$ & 0040 \\
\hline Respiratory acidosis & & $112(15.9)$ & $39(12.7)$ & $73(18.4)$ & 0.041 \\
\hline Hyper/hypoglycemia & & $56(7.9)$ & $22(7.2)$ & $34(8.5)$ & 0.503 \\
\hline Hyper/hyponatremia & & $48(6.8)$ & $19(6.2)$ & $29(7.3)$ & 0.566 \\
\hline Uremia & & $68(9.6)$ & $26(8.5)$ & $42(10.6)$ & 0.353 \\
\hline Metabolic acidosis & & $3(0.4)$ & - & $3(0.8)$ & - \\
\hline İnection & & $346(49.1)$ & $162(52.8)$ & $184(46.2)$ & 0.085 \\
\hline Intracranial mass & & $185(26.2)$ & $25(8.1)$ & $160(40.2)$ & 0.001 \\
\hline Medication ${ }^{\ddagger}$ & & $51(7.2)$ & $23(7.5)$ & $28(7.0)$ & 0.816 \\
\hline PRES & & 2 & - & 2 & - \\
\hline Arrhythmia & & $37(5.2)$ & $14(4.6)$ & $23(5.8)$ & 0.472 \\
\hline Multiple Etiology \#, n (\%) & & $386(56.5)$ & $158(51.5)$ & $228(57.3)$ & 0.124 \\
\hline
\end{tabular}

†Diabetes mellitus, HT, hypothyroidism, hypercholesterolemia, cerebrovascular disease, chronic renal failure, extra-thoracic malignancy and other systemic chronic diseases; łlsoniazid, rifampicin, moxifloxacin, macrolide, meropenem, ciprofloxacin, ampicillin, or mycophenolate mofetil; \#Coexistence of multiple factors that will be

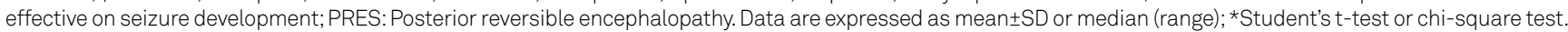


not differ significantly in terms of the presence of multiple factors $(\mathrm{p}=0.124$; Table 1$)$.

From the subjects diagnosed with tuberculosis, COPD, or hemoptysis, eight (4.3\%), fourteen (7.5\%), and four (2.2\%) of them had intracranial mass lesions, respectively. In addition, symptomatic seizures were observed in 157 (39.7\%) patients with a diagnosis of lung cancer (Table 2). In these patients, the etiological cause of seizures was an intracranial mass in $136(86.6 \%)$ patients and an infection in 71 (45.2\%) patients, and multiple factors were involved in the seizures of 97

Table 2. Primary diagnosis during hospitalization in all patients.

\begin{tabular}{|c|c|c|c|c|}
\hline & Total $n=705$ & Group I $n=307$ & Group II $n=398$ & $p$-value* \\
\hline $\begin{array}{l}\text { COPD/Respiratory } \\
\text { insufficiency, n (\%) }\end{array}$ & $185(26.2)$ & $123(40.1)$ & $62(15.6)$ & 0.001 \\
\hline Lung cancer, n (\%) & $179(25.4)$ & $22(7.1)$ & $157(39.7)$ & 0.001 \\
\hline Pneumonia, n (\%) & $89(12.6)$ & $75(24.4)$ & $14(3.5)$ & 0.001 \\
\hline Tuberculosis, n (\%) & $70(9.9)$ & $32(10.4)$ & $38(9.5)$ & 0.705 \\
\hline Lung transplant, n (\%) & $29(4.1)$ & - & $29(4.1)$ & - \\
\hline Hemoptysis, n (\%) & $24(3.4)$ & $5(1.6)$ & $19(4.8)$ & 0.001 \\
\hline Pleural effusion, n (\%) & $23(3.3)$ & $10(3.3)$ & $13(3.3)$ & 0.995 \\
\hline Asthma, n (\%) & $23(3.3)$ & $5(1.6)$ & $18(4.5)$ & 0.001 \\
\hline $\begin{array}{l}\text { Pulmonary embolism, } \\
\mathrm{n}(\%)\end{array}$ & $21(3.0)$ & $7(2.3)$ & $14(3.5)$ & 0.001 \\
\hline $\begin{array}{l}\text { Postentubation } \\
\text { stenosis, n (\%) }\end{array}$ & $16(2.3)$ & $6(2.0)$ & $10(2.5)$ & 0.622 \\
\hline Pneumothorax, n (\%) & $13(1.8)$ & $2(0.7)$ & $11(2.8)$ & 0.001 \\
\hline \multirow[t]{2}{*}{$\begin{array}{l}\text { Other diseases of the } \\
\text { lung, } n(\%)^{\dagger}\end{array}$} & $33(4.7)$ & $20(6.5)$ & $13(3.3)$ & 0.049 \\
\hline & 705 & $307(43.5)$ & $398(56.5)$ & 0.001 \\
\hline
\end{tabular}

COPD: Chronic obstructive pulmonary disease; † Interstitial lung disease, Behçet diseases, Churg Strauss Granulomatosis, Sarcoidosis etc; ${ }^{c}$ chi square test.

Table 3. Comparison of laboratory parameters between groups.

\begin{tabular}{|c|c|c|c|c|}
\hline & Total (n:705) & Group I (n:307) & Group II (n:398) & $p$-value ${ }^{*}$ \\
\hline Blood Glucose (mg/dl) & $94.6 \pm 41.2(47-431)$ & $95.6 \pm 43.9$ & $93.8 \pm 39.0$ & 0.573 \\
\hline Blood urea (mg/dl) & $42.9 \pm 19.3(11-187)$ & $41.4 \pm 17.2$ & $43.9 \pm 20.7$ & 0.078 \\
\hline Creatinine (mg/dl) & $0.8 \pm 0.4(0.14-3.7)$ & $0.79 \pm 0.3$ & $0.79 \pm 0.4$ & 0.998 \\
\hline Uric acid (mg/dl) & $4.0 \pm 2.4(0.3-21.9)$ & $4.1 \pm 2.8$ & $3.9 \pm 2.1$ & 0.291 \\
\hline $\mathrm{Na}^{+}(\mathrm{mEq} / \mathrm{L})$ & $140.2 \pm 6.9(132-165)$ & $140.2 \pm 7.2$ & $140.3 \pm 6.6$ & 0.895 \\
\hline WBC (cells $/ \mathrm{mm}^{3}$ ) & $12.7 \pm 7.4(3.4-36.0)$ & $13.1 \pm 7.4$ & $12.5 \pm 7.5$ & 0.301 \\
\hline RBC (cells/mm³) & $4.7 \pm 0.7(3.4-8.0)$ & $4.6 \pm 0.7$ & $4.7 \pm 0.6$ & 0.398 \\
\hline Sedimentation $(\mathrm{mm} / \mathrm{h})$ & $42.3 \pm 31.9(4-100)$ & $43.5 \pm 31.9$ & $41.4 \pm 31.8$ & 0.384 \\
\hline $\mathrm{CRP}(\mathrm{mg} / \mathrm{dl})$ & $21.9 \pm 27.4(0.1-109)$ & $22.4 \pm 26.8$ & $21.4 \pm 27.7$ & 0.627 \\
\hline $\mathrm{pCO}_{2}(\mathrm{mmHg})$ & $49.9 \pm 16.5(22-98.4)$ & $50.3 \pm 15.6$ & $49.7 \pm 17.2$ & 0.618 \\
\hline $\mathrm{pO}_{2}(\mathrm{mmHg})$ & $76.7 \pm 17.2(32-99.5)$ & $79.5 \pm 14.9$ & $74.5 \pm 18.5$ & 0.001 \\
\hline $\mathrm{HCO}_{3}(\mathrm{mEg} / \mathrm{lt})$ & $23.3 \pm 1.2(18.2-28.2)$ & $23.2 \pm 1.2$ & $23.3 \pm 1.2$ & 0.263 \\
\hline $\mathrm{pH}$ & $7.35 \pm 0.06(7.11-7.45)$ & $7.37 \pm 0.04$ & $7.34 \pm 0.66$ & 0.001 \\
\hline
\end{tabular}

*Student's t-test. Data are expressed as mean \pm SD or median (range). 
$(61.7 \%)$ patients. Of the patients who were admitted to the emergency department with first-time seizures and had an intracranial mass lesion, seven had primary lung cancer and two had pulmonary tuberculosis.

EEG was performed during the postictal period in 476 (67.5\%) patients and revealed focal findings in $118(16.7 \%)$ patients, generalized findings in 119 (16.9\%) patients, and normal findings in 239 (33.9\%) patients. Based on the clinical findings and EEG data, 184 (26.1\%) patients had focal seizures and $521(73.9 \%)$ patients had generalized seizures. A total of 147 (79.9\%) patients with focal seizures were in Group II and 270 (51.8\%) patients with generalized seizures were in Group I. Generalized seizures were more common in patients with seizures due to metabolic causes or infections $(\mathrm{n}=380 ; 77.4 \% ; \mathrm{p}=0.001$ and $\mathrm{n}=281 ; 81.3 \%$; $\mathrm{p}=0.001$, respectively) and patients with multiple etiological factors ( $n=266 ; 68.9 \%$; $\mathrm{p}=0.001$ ). Focal seizures were more common in patients with an accompanying intracranial mass lesion ( $\mathrm{n}=137 ; 74.1 \% ; \mathrm{p}=0.001)$.

Of all the patients that were followed-up due to seizures, the mortality rate was $5.6 \%(n=42)$. However, this rate did not differ significantly between the groups (Group I: $n=14 ; 4.6 \%$ and Group II: $n=28 ; 7.0 \% ; p=0.169$ ) and the mortality rate was significantly higher in patients with hypoxemia $(n=26 ; 9.7 \% ; \mathrm{p}=0.01)$, hypercapnia $(\mathrm{n}=27 ; 8.4 \% ; \mathrm{p}=0.013)$, and respiratory acidosis $(n=17 ; 14.8 \% ; p=0.001)$ (Table 4). Additionally, the point-biserial correlation analysis revealed a correlation between mortality and the mean arterial $\mathrm{PaCO}_{2}, \mathrm{PaO}_{2}$, and $\mathrm{pH}$ values (Figure 1).

Table 4. Factors affecting hospital mortality.

\begin{tabular}{|c|c|c|c|c|}
\hline & & Dead $n=42(6.0 \%)$ & Alive $n=663(94,0 \%)$ & $p$-value* \\
\hline Group, n (\%) & & & & 0.169 \\
\hline I & $307(43.5)$ & $14(4.6)$ & $293(95.4)$ & \\
\hline$\|$ & $398(56.5)$ & $28(7.0)$ & $370(93.0)$ & \\
\hline \multicolumn{5}{|l|}{ Presence of hypoxemia, n (\%) } \\
\hline Present & $269(38.2)$ & $26(9.7)$ & $243(90.3)$ & 0.001 \\
\hline Absent & $436(61.8)$ & $16(3.7)$ & $420(96.3)$ & \\
\hline Presence of hypercapnia, n (\%) & & & & 0.013 \\
\hline Present & $323(45.8)$ & $27(8.4)$ & $296(91.6)$ & \\
\hline Absent & $382(54.2)$ & $15(3.9)$ & $367(96.1)$ & \\
\hline \multicolumn{5}{|c|}{ Presence of respiratory acidosis, n (\%) } \\
\hline Present & $112(15.9)$ & $16(14.3)$ & $96(85.7)$ & 0.001 \\
\hline Absent & $592(84.1)$ & $26(4.4)$ & $566(95.6)$ & \\
\hline
\end{tabular}

*chi square test.

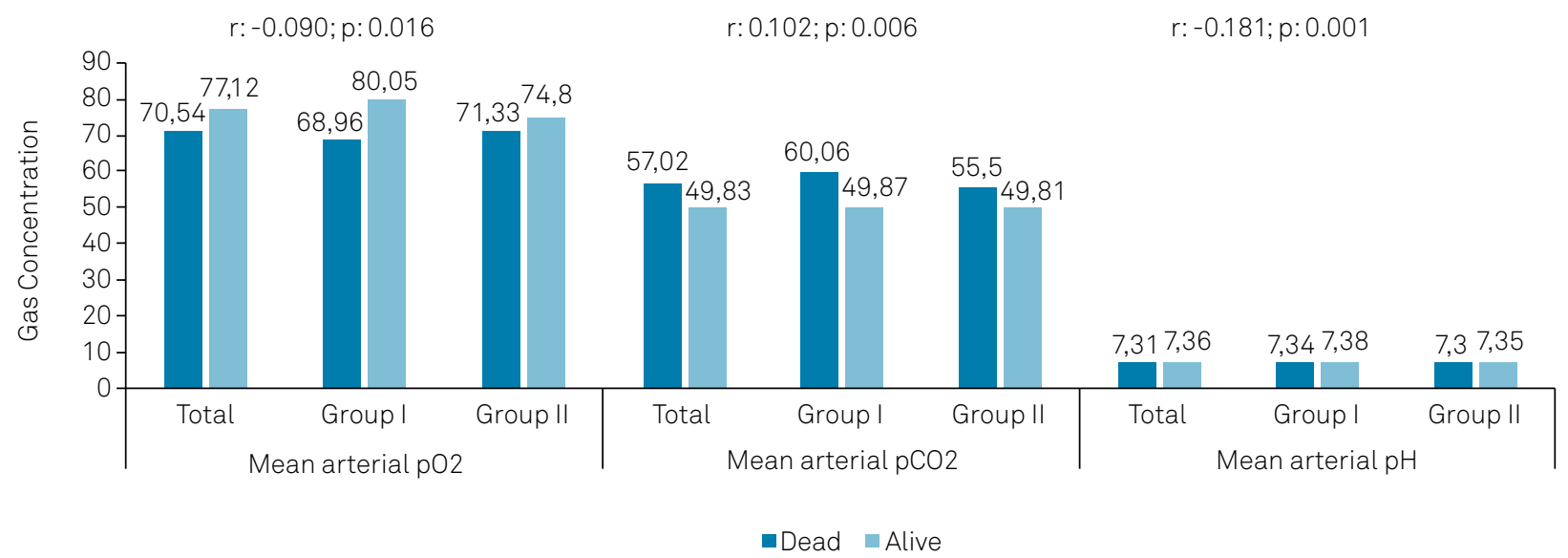

Figure 1. Correlation analysis between hospital mortality and changes in blood gas concentration. 


\section{DISCUSSION}

This study shows that symptomatic seizures constitute the majority of epileptic seizures and blood gas exchange abnormalities play a significant role on mortality in patients with respiratory disease and epileptic seizures. The predominant etiological cause of symptomatic seizures was the metabolic changes; the most influent cause of which was decrease in mean arterial $\mathrm{PaO}_{2}$ and $\mathrm{pH}$ values. In both groups, we found more than one etiological factor for the development of seizure. The reported prevalence rate for symptomatic seizures ranges from 3.7-22.5\% and these types of seizures are more common in adolescents and elderly males ${ }^{2,11,12}$. In the present study, symptomatic seizures were more common in the assessed patients but Groups I and II did not differ significantly in terms of age and gender, which can be explained by the more frequent occurrence of respiratory diseases in elderly and male patients ${ }^{13}$.

Acute symptomatic seizures can develop as the result of multiple conditions, including acute cerebrovascular diseases, traumatic brain damage, CNS infections, medication use, substance and alcohol use, metabolic and electrolyte disturbances, encephalopathy, and eclampsia ${ }^{11}$. In the existing literature, most studies have focused on the association between respiratory diseases and seizures; no retrospective or prospective studies have assessed a large number of patients. Patients with pulmonary embolism who present with symptomatic seizures account for fewer than $1 \%$ of all patients with symptomatic seizures, and cases of pulmonary hypertension with symptomatic seizures are rare $\mathrm{r}^{7,14,15}$. Fred was the first author to describe a case of pulmonary embolism that presented with generalized tonic-clonic seizures following an abrupt-onset syncope ${ }^{7}$. Marine implicated transient right ventricular failure in the psychopathology of epileptic seizures in patients with pulmonary embolism and suggested a role for transient global cerebral hypoperfusion caused by decreased cardiac output ${ }^{14}$. Similarly, nocturnal seizures observed in patients with pulmonary hypertension can be explained by episodic decreases in cardiac output and cerebral perfusion ${ }^{15}$.

In clinical practice, epileptic seizures associated with electrolyte and metabolic disturbances are commonly encountered in intensive care units and emergency clinics $^{16,17}$. For example, metabolic causes are responsible for $10 \%$ of adult patients who have seizures for the first time in the emergency room ${ }^{17}$. Moreover, abnormalities in serum glucose, urea, creatinine, or electrolyte $\left(\mathrm{Na}^{+}, \mathrm{Ca}^{+2}\right.$, etc.) levels, and less frequently, parameters of arterial blood gases, also contribute to the etiology of seizures ${ }^{18-21}$. Metabolic disturbances, deficiencies in the substrates required for cellular metabolism or cell membrane functions, the intracellular accumulation of toxic substances, and particularly changes in plasma osmolality and electrolyte disturbances, increase neuronal excitability and subsequently increase the risk of developing seizures $^{22,23}$. According to our results, consultation request was less observed in intensive care units than in chest clinics. This may be related to the frequent use of antisedatives agents such as midazolam and propofol which have antiepileptic effects in intensive care units.

The present study found that metabolic causes ranked first among the potential etiological factors associated with seizures in patients with primary epilepsy and those with symptomatic seizures. In contrast, Groups I and II did not differ significantly in any of the biochemical or infection parameters. However, the mean arterial $\mathrm{PaO}_{2}$ and $\mathrm{pH}$ values were significantly lower in Group II. Accordingly, the prominent presence of hypoxemia or respiratory acidosis in patients with symptomatic seizures who had a healthy neuronal network might be an important parameter for indicating the potential effects of changes in blood gas levels on the seizure threshold.

In the present study, generalized seizures were common in patients with a predominance of metabolic and infection parameters, whereas focal seizures were more common in patients with a comorbid intracranial mass. Metastatic brain tumors account for $10-30 \%$ of all intracranial tumors in adults, and the most common tumors that metastasize to the brain are lung carcinomas, which account for $20 \%$ of all cases ${ }^{24-26}$. Seizures are observed in $10-50 \%$ of patients with metastatic brain tumors and tend to manifest as focal motor seizures $^{27,28}$. The localization of the mass lesion, its histological features, and other peritumoral factors are influential in the development of focal seizures ${ }^{29}$. Consistent with the literature, the occurrence of focal seizures in the present patients was mostly associated with intracranial mass lesions and metastatic brain tumors, which were particularly common in patients with lung cancer.

Mortality rates and frequency of recurrent seizures differ between patients with symptomatic seizures and patients without a provoked seizure. For example, early diagnosis and appropriate management can prevent the development of morphological changes, so defining metabolic conditions is important for making a prognosis ${ }^{20,30}$. Experimental studies have demonstrated that prolonged episodes of hypoxia caused by a notable decrease in $\mathrm{pO}_{2}$ saturation may increase the rate and severity of hypoxic ischemic brain damage ${ }^{31,32}$. Furthermore, studies have found associations between epileptic seizures and the severity of brain damage and acute mortality ${ }^{33-35}$. Severe and prolonged postictal hypoxemia and hypercapnia in patients with partial onset seizures cause impairments in respiratory functions and increase the risk of sudden unexpected death in epilepsy (SUDEP) $)^{36-39}$. Furthermore, peri-ictal apnea associated with prolonged severe hypoxemia could be a potential predictor of SUDEP ${ }^{40}$. The present findings, indicating correlations between mortality and the presence of hypoxemia, hypercapnia, and respiratory acidosis, suggest that these parameters may affect the prognosis 
of patients with a respiratory disease who have epileptic seizures. Abnormalities in blood gases in patients with a respiratory disease may affect mortality because of possible yet unknown mechanisms in seizure pathophysiology, and new large-scale studies are needed to reveal these possible mechanisms.

The most important limitation of the present retrospective cross-sectional study was the unavailability of data regarding recurrent seizure episodes in patients with symptomatic seizures following the hospitalization period. Additionally, no follow-up data were available for patients placed on antiepileptic therapies, and data regarding the effects of seizures in patients with respiratory diseases on their long-term prognoses were missing in both Group I and Group II.

In conclusion, the present study found that seizures were frequent in patients who were hospitalized due to a respiratory condition. Additionally, as evidenced by changes in blood gases, hypoxemia and respiratory acidosis were especially associated with the development of symptomatic seizures. In patients who were hospitalized for respiratory system diseases and experienced seizures, the presence of hypoxemia, hypercapnia, and respiratory acidosis were correlated with mortality. Therefore, it will be important to consider carefully these factors if they are observed during the peri-ictal period.

\section{References}

1. Annegers JF, Hauser WA, Lee RJ, Rocca WA. Incidence of acute symptomatic seizures in Rochester, Minnesota, 1935-1984. Epilepsia. 1995 Apr;36(4):327-33. https://doi.org/10.1111/j.1528-1157.1995. tb01005.x

2. Beghi E, Carpio A, Forsgren L, Hesdorffer DC, Malmgren K, Sander $\mathrm{JW}$, et al. Recommendations for a definition of acute symptomatic seizure. Epilepsia. 2010 Apr;51(4):671-5. https://doi.org/10.1111/ j.1528-1167.2009.02285.x

3. Stables JP, Bertram EH, White HS, Coulter DA, Dichter MA, Jacobs MP, et al. Models for epilepsy and epileptogenesis: report from the NIH workshop, Bethesda, Maryland. Epilepsia. 2002 Nov; 43(11):14101412. https://doi.org/10.1046/j.1528-1157.2002.06702.x

4. Hauser W, Rich S, Annegars JF, Anderson VE. Seizure recurrence after a 1st unprovoked seizure: an extended follow-up. Neurology. 1990 Aug;40(8):1163-70. https://doi.org/10.1212/wnl.40.8.1163

5. Hunt DP, Tang K. Long QT syndrome presenting as epileptic seizures in an adult. Emerg Med J. 2005 Aug;22(8):600-1. https://doi. org/10.1136/emj.2003.007997

6. Duplyakov D, Golovina G, Lyukshina N, Surkova E, Elger CE, Surges R. Syncope, seizure-induced bradycardia and asystole: two cases and review of clinical and pathophysiological features. Seizure. 2014 Aug;23(7):506-11. https://doi.org/10.1016/j.seizure.2014.03.004

7. Fred HL, Yang M. Sudden loss of consciousness, dyspnea, and hypoxemia in a previously healthy young man. Circulation. 1995;91(12):3017-9. https://doi.org/10.1161/01.CIR.91.12.3017

8. Volz EE, Jasani N. Seizure as a presentation of pulmonary embolism. J Emerg Med. 2014 Jan;46(1):e1-4. https://doi.org/10.1016/j. jemermed.2013.08.057

9. Saudek CD, Herman WH, Sacks DB, Bergenstal RM, Edelman D, Davidson MB. A new look at screening and diagnosing diabetes mellitus. J Clin Endocrinol Metab. 2008 Jul;93(7):2447-53. https://doi. org/10.1210/jc.2007-2174

10. Cryer PE, Davis SN, Shamoon H. Hypoglycemia in diabetes. Diabetes Care. 2003 Jun;26(6):1902-12. https://doi.org/10.2337/ diacare.26.6.1902

11. Nwosu PO, Nwosu MC, Nwosu MN. epidemiology of acute symptomatic seizures among adult medical admissions. Epilepsy Res Treat. 2016;2016:4718372. https://doi.org/10.1155/2016/4718372

12. Hauserand WA, Beghi E. First seizure definitions sand worldwide incidence and mortality. Epilepsia. 2008 Jan;49(1):8-12. https://doi. org/10.1111/j.1528-1167.2008.01443.x

13. Ntritsos G, Franek J, Belbasis L, Christou MA, Markozannes G, Altman P, et al. Gender-specific estimates of COPD prevalence: a systematic review and meta-analysis. Int J Chron Obstruct Pulmon Dis. 2018 May;10(13):1507-14. https://doi.org/10.2147/COPD.S146390
14. Marine JE, Goldhaber SZ. Pulmonary embolism presenting as seizures. Chest. 1997 Sep;112(3):840-2. https://doi.org/10.1378/chest.112.3.840

15. Izzo A, McSweeney J, Kulik T, Khatwa U, Kothare SV. "Nocturnal seizures" in idiopathic pulmonary arterial hypertension. J Clin Sleep Med. 2013;9(10):1091-2. https://doi.org/10.5664/jcsm.3094

16. Murthy JM, Yangala R Acute symptomatic seizures — incidence and etiological spectrum: a hospital-based study from South India. Seizure. 1999 May;8(3):162-5. https://doi.org/10.1053/seiz.1998.0251

17. Jagoda A, Gupta K. The emergency department evaluation of the adult patient who presents with a first-time seizure. Emerg Med Clin North Am. 2011 Feb;29(1):41-9. https://doi.org/10.1016/j.emc.2010.08.004

18. Nigro N, Winzeler B, Suter-Widmer I, Schuetz P, Arici B, Bally M, et al. Symptoms and characteristics of individuals with profound hyponatremia: a prospective multicenter observational study. J Am Geriatr Soc. 2015 Mar;63(3):470-5. https://doi.org/10.1111/jgs.13325

19. Han P,Trinidad BJ, Shi J. Hypocalcemia-induced seizure: demystifying the calcium paradox. ASN Neuro. 2015 Mar;7(2). https://doi. org/10.1177/1759091415578050

20. Castilla-Guerra L, del Carmen Fernández-Moreno M, López-Chozas JM, Fernández-Bolaños R. Electrolytes disturbances and seizures. Epilepsia. 2006 Dec;47(12):1990-8. https://doi.org/10.1111/j.15281167.2006.00861.x

21. Yun C, Xuefeng W. Association between seizures and diabetes mellitus: a comprehensive review of literature. Curr Diabetes Rev. 2013 Jul;9(4):350-4. https://doi.org/10.2174/15733998113099990060

22. Messing R, Simon R. Seizures as a manifestation of systemic disease. Neurol. Clin. 1986 Aug;4(3):563-84.

23. Schwartzkroin PA, Baraban SC, Hochman DW. Osmolarity, ionic flux, and changes in brain excitability. Epilepsy Res. 1998 Sep;32(1-2):27585. https://doi.org/10.1016/s0920-1211(98)00058-8

24. Johnson JD, Young B. Demographics of brain metastasis. Neurosurg Clin N Am. 1996 Jul;7(3):337-44.

25. Wen PY, Loeffler JS (1999). Management of brain metastases. Oncology (Williston Park). 1999 Jul;13(7):941-54, 957-61; discussion 961-2, 9.

26. Barnholtz-Sloan JS, Sloan AE, Davis FG, Vigneau FD, Lai P, Sawaya RE. Incidence proportions of brain metastases in patients diagnosed (1973 to 2001) in the Metropolitan Detroit Cancer Surveillance System. J Clin Oncol. 2004 Jul;22(14):2865-72. https://doi. org/10.1200/JC0.2004.12.149

27. Lynam LM, Lyons MK, Drazkowski JF, Sirven JI, Noe KH, Zimmerman RS, et al. Frequency of seizures in patients with newly diagnosed brain tumors: a retrospective review. Clin Neurol Neurosurg. 2007;109(7):634-8. https://doi.org/10.1016/j.clineuro.2007.05.017

28. Newton H. Neurologic complications of systemic cancer. Am Fam Physician. 1999 Feb;59(4):878-86. 
29. Alentorn A, Hoang-Xuan K, Mikkelsen T. Presenting signs and symptoms in brain tumors. Handb Clin Neurol. 2016;134:19-26. https://doi.org/10.1016/B978-0-12-802997-8.00002-5

30. Hesdorffer DC, Benn EK, Cascino GD, Hauser WA. Is a first acute symptomatic seizure epilepsy? Mortality and risk for recurrent seizure. Epilepsia. 2009 May;50(5):1102-8. https://doi.org/10.1111/ j.1528-1167.2008.01945.x

31. Adhami F, Liao GH, Morozov YM, Schloemer A, Schmithorst VJ, Lorenz JM, et al. Cerebral ischemia-hypoxia induces intravascular coagulation and autophagy. Am J Pathol. 2006 Aug;169(2):566-83. https://doi.org/10.2353/ajpath.2006.051066

32. Vannucci SJ, Willing LB, Goto S, Alkayed NJ, Brucklacher RM, Wood $\mathrm{TL}$, et al. Experimental stroke in the female diabetic, $\mathrm{db} / \mathrm{db}$, mouse. J Cereb Blood Flow Metab. 2001 Jan;21(1):52-60. https://doi. org/10.1097/00004647-200101000-00007

33. Olson EE, McKeon RJ. Characterization of cellular and neurological damage following unilateral hypoxia/ischemia. J Neurol Sci. 2004 Dec;227(1):7-19. https://doi.org/10.1016/j.jns.2004.07.021

34. Wang J, Wu C, Peng J, Patel N, Huang Y, Gao X, et al. Early-Onset Convulsive Seizures Induced by Brain Hypoxia-Ischemia in Aging Mice: Effects of Anticonvulsive Treatments. PLoS One. 2015 Dec;10(12):e0144113. https://doi.org/10.1371/journal.pone.0144113
35. Wu CP, Wang J, Peng J, Patel N, Huang Y, Gao X, et al. Modeling early-onset post-ischemic seizures in aging mice. Exp Neurol. 2015 Sep;271:1-12. https://doi.org/10.1016/j. expneurol.2015.04.018

36. Seyal M, Bateman LM, Albertson TE, Lin TC, Li CS. Respiratory changes with seizures in localization-related epilepsy: analysis of periictal hypercapnia and airflow patterns. Epilepsia. 2010 Aug;51(8):1359-64. https://doi.org/10.1111/j.15281167.2009.02518.x

37. Bateman LM, Li CS, Seyal M. Ictal hypoxemia in localization-related epilepsy: analysis of incidence, severity and risk factors. Brain. 2008;131(12):3239-45. https://doi.org/10.1093/brain/awn277

38. Devinsky O. Sudden, unexpected death in epilepsy. N Engl J Med. 2011 Nov;365:1801-11. https://doi.org/10.1056/NEJMra1010481

39. Moseley BD, Britton JW, Nelson C, Lee RW, So E. Periictal cerebral tissue hypoxemia: a potential marker of SUDEP risk. Epilepsia. 2012 Dec;53(12):e208-11. https://doi.org/10.1111/j.15281167.2012.03707.x

40. Lacuey N, Zonjy B, Hampson JP, Rani MRS, Zaremba A, Sainju $\mathrm{RK}$, et al. The incidence and significance of periictal apnea in epileptic seizures. Epilepsia. 2018 Mar;59(3):573-82. https://doi. org/10.1111/epi.14006 